Refereed Papers 


\section{Notation and Crocodiles: The architecture of Steinberg's Magnolia Motel}

\section{Sarah Treadwell}

Cartoonist Steinberg's well known and celebrated ink drawings frequently involve architecture and the discipline is often the subject of his acerbic wit and melancholic sharp insights; his wonderful covers for the New Yorker have been understood as commentaries on urban conditions and American dreams of progress. Steinberg (1914-1999), born in Romania but known for his observations of a wider world, initially studied in philosophy and subsequently in architecture, and his drawings offer critiques of architecture, cities, geometry and those parts of human life that resist the clean orderliness of basic, Euclidean structures. Steinberg suggested that the time spent at the Reggio Politecnico studying architecture "brought purpose to the continuous line of my drawing ... a way of looking at writing from my illiterate days" (Smith 2007: 26). This paper considers a series of drawings that Steinberg included in his collection, The Labyrinth, published in 1960. The selected drawings are far from the stately skylines of New York, addressing instead the everyday yet haunting architecture of the Magnolia Motel.

In interviews recorded between 1974 and 1977 Steinberg spoke of the difficulties of drawing from life and the need to first give up on all commonplaces of the drawing subject: "More difficult than inventing is giving up on accumulated virtues. The things you discovered yesterday are no longer valid. It's impossible to find anything new without first giving something up" (Steinberg and Buzzi 2002: 70). Motels have already ceded from virtue and while architecture is generally constrained by the known, the anticipated and a heavy history, the quick wit of motels, subject to Steinberg's drawing, catch at the possibilities of invention.

Architect and architectural theorist Marco Frascari, who has written about Saul Steinberg's marvellous creations, in a diatribe about the contemporary nature of architectural drawing, asserted "that current architectural graphic productions have reached an unchangeable and highly sterile phase of inert classifications and taxonomies, based on a pseudo-transparency of scope and a pseudo-scientific justification of the functions and roles carried out by the different kinds of architectural representation" (Frascari 2007b: 1). The motel as a type might be the site of sterile excess but Frascari's desire for a fluid, fertile graphic engagement with architecture drives this analysis of Steinberg's Magnolia Motel drawings, which will be considered as an aberrant and productive architectural notation.

Frascari's own writings on the architectural plan give insight into Steinberg's inscriptions because Steinberg utilises the disciplinary conventions of architectural drawing, plans and perspectives, distorting and remaking them, producing new conditions of programmatic description. Architectural drawings, under his manipulations, become figural, destabilising habitual representational systems. The Magnolia Motel drawings can be viewed as records of social behaviour steeped 
with emotional emanations: images of an unattainable condition of home slipping into and out of categories of architecture. Operating between writing and drawing, Steinberg's images are critically shaped by the architectural plan, the drawing that cuts horizontally through the social life of a building and yet is recognised as an abstraction. This essay considers the effects of Steinberg's disruptive figurations in drawings that comment on the social, material and atmospheric conditions of life in a motel.

Motels have long figured in the popular press as sites of transgression, violence and dubious commerce. Stories of drug dealing, prostitution and mayhem colour this architectural type, which also houses cosy versions of the domestic. The motel in Alfred Hitchcock's enduring horror film Psycho (1960), the site of the bloody shower scene, is set beside a proper (and unnerving) Gothic house. As constructed by Hitchcock, Bates Motel serves as both a sign of modernity with its horizontality, close relationship to the car and obsessive attention to plumbing, and as a counterpoint to the stifling madness of the single-family home.

Multiple and reoccurring, unlike the singular suburban home, the motel is in Steinberg's much-reproduced drawings a repetitious home that travels, demanding only a fleeting allegiance: it is a space for the convergence of the fixed and the mobile. The motel is a transit-form of the domestic that could be seen as complicating the oppositional structure that cultural theorist Meaghan Morris pointed out in her essay on the Henry Parkes Motel, where the home is inscribed as the site of "both frustrating containment (home as dull) and of truth to be rediscovered (home as real)" (Morris 1993: 252). Families occupy the motel as a home away from home, alien and desired, different and familiar.

In the process of being replaced by holiday resorts, motels in New Zealand, remote and necessarily out of date and time, persist on the edges of motorways, lakes and volcanic landscapes. The car, following the endless white line of the road across landscapes, through towns, is intercepted by a motel knowingly placed within the driver's vision on the outskirts of town. Premised on a short life with frequent renovations and typically low rise, motels consist of car park, bedroom, basic cooking facilities, and a bathroom. They provide accommodation that is relatively anonymous and reasonably cheap in comparison with hotel accommodation and, while they are disparagingly charged with a temporary and second-rate homeliness, they might also be seen more positively through Steinberg's drawings, as an imagining of everyday life without routines of ownership, without closure.

Around the time of the drawings of the Magnolia Motel, Michel Foucault located the motel as a form of heterotopia: "This type of heterotopia, which has practically disappeared from our civilizations, could perhaps be found in the famous American motel rooms where a man goes with his car and his mistress and where illicit sex is both absolutely sheltered and absolutely hidden, kept isolated without however being allowed out in the open" (Foucault 1967). In the limited quarters of the motel the impossibility of separation or personal distance is combined with the expansive freedom of the open road. The potential of mobility becomes disconnected from notions of progress and accumulative constructions of home, and allied instead to chance and desire.

Foucault described heterotopic sites as relations of proximity or propinquity, associated with deviancy, and his analysis was framed in reaction to the conservative morality of that period of social change. Nabokov's descriptions of 
motels in his novel Lolita in 1955 also would have promoted the association of the motel with both pleasure and cruelty. Humbert recounts: "To any other type of tourist accommodation I soon grew to prefer the Functional Motel - clean, neat, safe nooks, ideal places for sleep, argument, reconciliation, insatiable illicit love" (Nabokov 2000: 143). The idea of the motel as a housing of deviancy continues to be registered in both contemporary, popular commentaries and in the physical planning of the motel.

\section{Magnolia Motel}

The Magnolia Motel is both a persistent idea and a building. The material version of the motel, in which Steinberg could have stayed on his trip to Kentucky, Tennessee and West Virginia in 1957 (Rosenberg 1978: 242), was recorded on the website Vanishing America and included photographs of the Magnolia Motel from the 1950s, the 1970s and in more recent times. Located at Knoxville, Tennessee, it is depicted nostalgically as an architectural sign of a golden past and in its contemporary condition as the haunt of prostitutes. The neon sign of the motel is now missing but the Magnolia Motel remains mythical, fictive and inaccessible there is always "no vacancy" (according to Steinberg's drawing).

Steinberg drew the Magnolia Motel at least four times in The Labyrinth and his drawings include two site plans, a plan, a perspective sketch and a key detail of a general condition of "motelness" which is positioned beneath the Magnolia Motel plan. The plan drawing, like a folded-out developed surface drawing, includes elevational information, and the combination of the drawings provides an almost complete architectural design of the motel. Shaped with a sinuous, stuttering line, the architectural drawings enact the air of freedom and comic moodiness that pervades the various formations of the Magnolia Motel. The motel drawings are each "read" following Steinberg's own instructions: "I am a writer who draws" (Willer 2009: 5) and with a specifically architectural eye.

\section{Arrival}

On the edge of the long highway a neon sign looms up as the automobile, imaginatively finned, elongated and gleaming, speeds along: a jumble of block letters stacking up in identification of product and place - a sign illuminating participation in a network of virtual relations, signaling intersection and a conjunction of services. The sign points out that the motel is air-conditioned (a longed-for relief from the hot, humid interior of the leather-clad car); it has a television, is a member of the AAA, is named Magnolia and has no vacancies. The car speeds off into the night.

The sign leapt out of the darkness and from the page of Steinberg's book. With its reference to service the sign is an indexical link to networks of commerce, advertising and exchange. It offers identity and the formal aspects of the sign are linked to a striving for modernity and newness subject to the cyclings of fashion. Visible from a distance, the motel sign, like most advertising, projects and seduces; the words demand attention but in capitals they are subject to a 13 per cent reduction in reading speed, signs approach too quickly and visibility is fleeting (Rehe 2000: 106). 
I. http://www.neonmona.org/flash/index. html Visited 2005.
The motel in Steinberg's drawing exists under a moon, always at night. The moon is a thin crescent, cuckold horns pointing into a sky rendered wide and bare. The crescent moon, marking (illicit) beginnings and endings, echoes, in reverse, the form of the curved word on the sign: "air-conditioned". Glowing like the moon, neon effects are hinted at in the drawing of the multiple, parallel brake lights that stutter behind the cars pulled up at the units. For the Museum of Neon Art neon is "[n]ot just for sleazy motels anymore"1 but neon, like motels, is either bright or swallowed up in darkness, pure pleasure or dubious; neon reeks of commerce and exchange. The violence and complex social negotiations that remain hidden in the family home are manifest in the secrecy of a motel advertised by glowing neon. Steinberg admired American artist Edward Hopper for his rendering of neon light (Steinberg and Buzzi: 2002, 59) and Hopper is remembered for his motel paintings of anxious expectancy (Treadwell 2005).

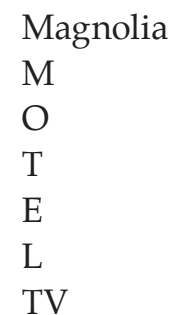

Air conditioned

AAA

No vacancy

Words as formal constructions, as building blocks, gain ascendancy. The motel drawings in The Labyrinth are heavy with words and Steinberg refuses their usual orderly, linear progress. In other drawings in The Labyrinth ornaments and mazes replace words in speech bubbles, and clouds of smoke and elaborate curlicues are spoken. Instead of words, figures shout with angular marks, talk dirty with smudges and blots, seduce with convoluted meaningless calligraphy. Drawings replace the social agreement of words with representations of physical (albeit ephemeral) formal conditions of the sounds of words in a comic complication of usual privileging of writing over drawing.

When, in The Labyrinth collection, Steinberg draws words rather than writing them (if such a distinction can momentarily be made) the words enact their content: the word HELP falls with an exclamation, the letter E crunches up the letter A on table T. The word SWINDLE starts with a flourish and conceals its ending; tremulous words, "Maybe" and "Perhaps", are drawn teetering on a seesaw of indecision. Steinberg draws his words and writes his drawings. Words become things, material conditions of themselves, unexpectedly animate and fleshy. In the Magnolia Motel everyday life produces a Steinberg effect and the motel sign is all words. It repeats the ordinary appearance of signs that string along the highways where the support or structure, on which the words depend, is erased and there are only words and symbols against the dark sky in an abbreviated self-sufficiency that recalls the domestic condition of the motel. In the Magnolia Motel sign Steinberg undermines any perceptible substance with an anthropomorphic addition of two small legs unlikely to support the weight of stacked-up words. 


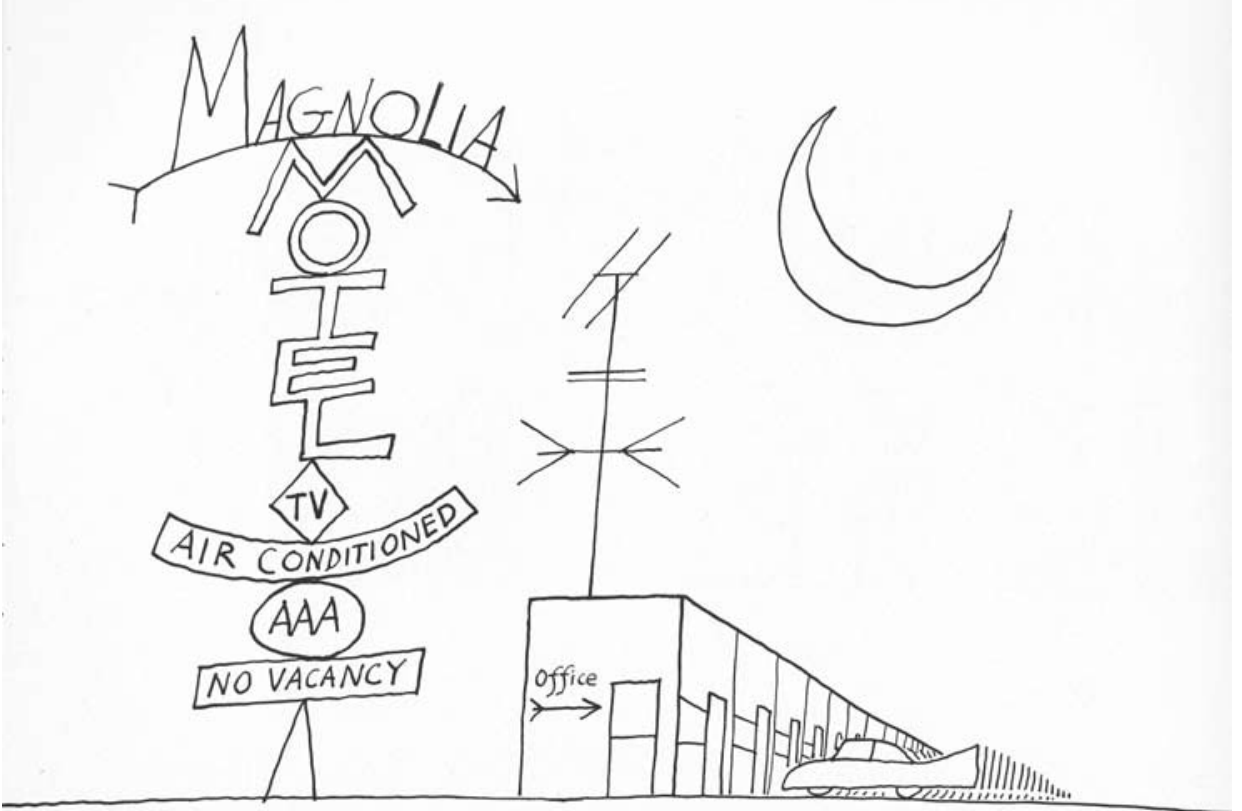

The motel sign is the most important thing in Steinberg's drawing - the peaks of the $\mathrm{M}$ in Magnolia, mountain-like, rise above the moon. The word "Magnolia" arches across a curved arrow following the curvature of the earth to arrive at this particular location. And with its name the motel is situated within the "pure, magnolia-scented fantasy of the Old South" (Bloomer 1998: 52). The drawings were made just prior to the Civil Rights Act of 1964 that outlawed discrimination in hotels, motels, restaurants, theaters, and all other public accommodations, and the white petalled "Magnolia Motel could be read as the late, last flowering of the segregated south"2. The Magnolia Motel has no other evidence of the Southern fantasy: no lawns, no trees, no genteel behaviour, just wires and letters, boxes and cars assembled under a moon. Nevertheless the word Magnolia, with the roundness of its $\mathrm{O}$ and the emphasised softness of the $\mathrm{L}$ (the lines that construct the letter are a little heavier) becomes oily, carrying a trace of lingering lemonsweet fragrance.

Frascari in his essay, "Architectural Synathesia: A hypothesis on the makeup of Scarpa's Modernist architectural drawings," retells Rabelais' story of Gargantua and Pantagruel when handfuls of frozen words are thrown onto the deck of a ship. Words that in their frozen state could not be heard but could be imagined through associations with colour and form; as the words thawed they could be heard but not understood, being in a unknown language. In a Steinbergian manner Frascari sees that these acts of transubstantiation make the invisible order of words momentarily visible and palpable through configurations of the noise/signs in material form (Frascari 2010). Frozen words, ice-coated and glittering, promise the unknown, and skittering across the surface, already subject to unpredictable inclinations, the words, like the blocked words in Steinberg's volumes, shift towards and away from predictable orders, jumbling into new associations.

Steinberg's Magnolia Motel drawings have something of Frascari's synesthetic effects as the black ink lines operate spatially, vibrating with electricity on the page in the cold night air; a chill of temperature and excitement emanates from the drawing. Frascari points out the impossibility of treating architectural drawings as neutral information, arguing instead that drawings make architecture with their own particular characteristics. Steinberg, for example, employs perspective, not to shape regular pictorial space, but rather as a method of stretching out the ground, implying the wide space of the highway and the inconsequential
Saul Steinberg Magnolia Motel Perspective (C) Saul Steinberg, 1960/ ARS.Licensed by VISCOPY 2010.

2. A description offered by the anonymous reader of this paper for Interstices. 


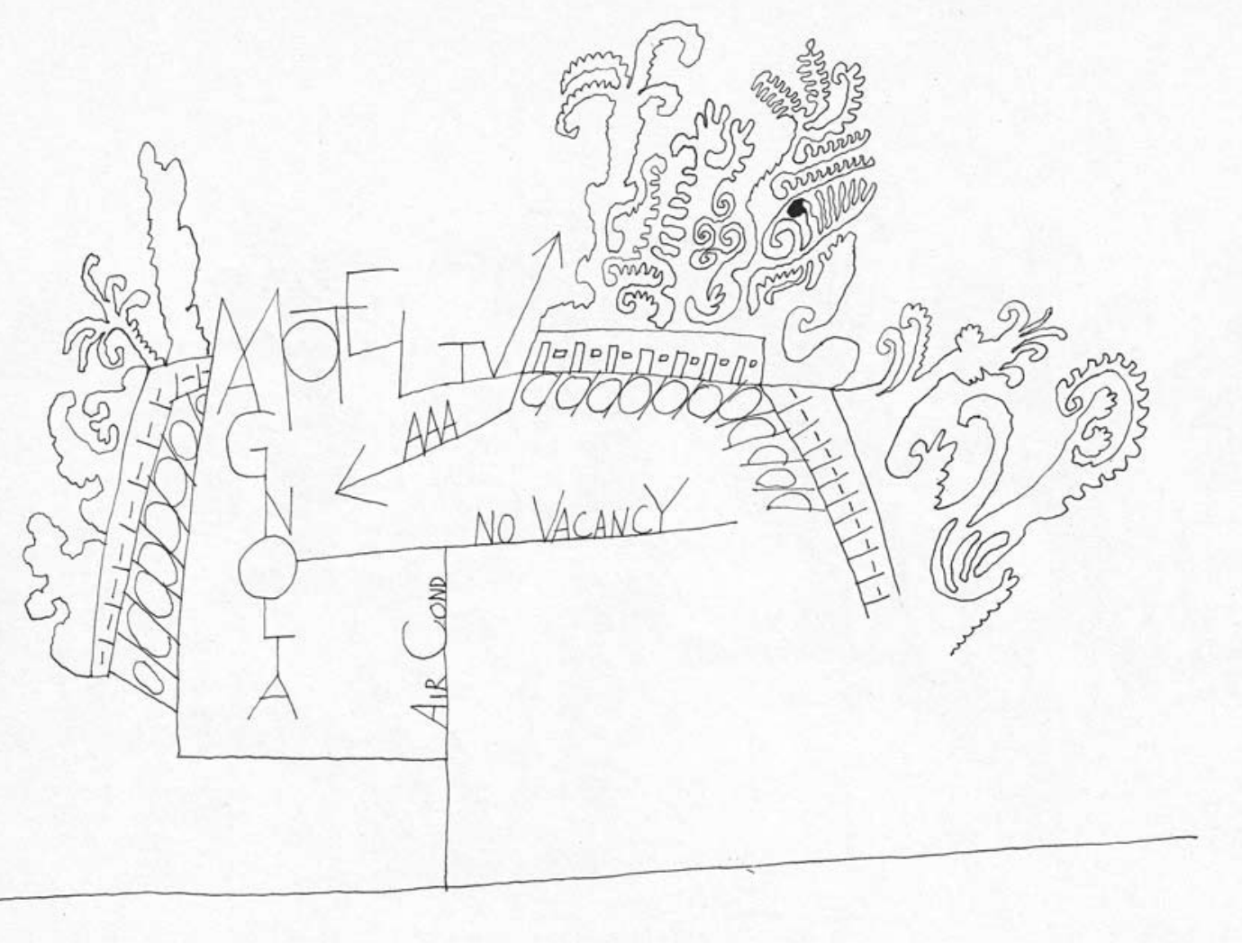

Saul Steinberg Magnolia Motel Plan (C) Saul Steinberg, 1960/ARS.Licensed by VISCOPY 2010. nature of the architecture on its edge. And if the pictured sign is understood as notation that shapes the Magnolia Motel, then it is notation that produces the architecture of the Magnolia Motel itself as a sign. The drawn words construct the motel as precariously founded, insubstantial and determinedly graphic.

Graphic is an appropriate word for the work of Steinberg in that it underlines the linear nature of his drawing: the variable lines alluding to script, pattern and notation even when illegible. When Steinberg works with the legibility of the sign, when he writes out words in boxes stacked up in the air, it is the graphic nature of the motel that is being proffered. The word "graphic", as well as alluding to drawing and the inevitable entwining of drawing/writing, also refers to a vivid everyday quality, something almost too visible. Walter Benjamin wrote of a "heightened graphicness" in his images in The Arcades Project and this phrase conveys something of the stripped yet ornamental quality in the drawings of the Magnolia Motel (Benjamin 1999: [N26] 461). Whereas graphicness might be seen as a resistance to consumption, with its suppression of materiality, it is made fat in Benjamin's images through the excesses of production.

Graphicness (in pornography or current filmic depictions of violence) is a vivid condition and is aligned with the motel and its sensitivity to the corporeal: to hand marks, fingerprints, stray hairs and calligraphic traces of the body. Marco Frascari wrote that "[d]rawings become aromatic-chromatic-visual tools to flavor buildings" (Frascari 2010), and Steinberg's graphic line records the taste of glaring neon, the stripped materiality and the slight bodily decay of the Magnolia Motel. In the hesitations, in the fluidity and congealing edges of the linear constructions, the social agendas of the motel are conveyed.

The sign that, in the perspective drawing of the Magnolia Motel, is simultaneously ornament, identity, architectural type and presentation of services, has become separated from inhabitable space. Qualities that conventionally assert architecture have, in Steinberg's image, an independence that sets occupancy to one side. The sign implies a new architectural species, an anthropomorphic figure that, pylon-like, transmits signals with Hejdukian qualities. John Hejduk was an architect who "eschewed traditional typology for anthropomorphic and 
animal-like buildings that were hybrids of simple abstract geometries and idiosyncratic figuration. These operated like Trojan horses, providing the architect with vacant protagonists through which to sneak in emotion and meaning" (Meredith 2002). Steinberg similarly suggests architecture as an anthropomorphic or zoomorphic node in a network or systemic formulation; unmistakably in the cranky typography, and the faint odour of flowers (not to forget the shaky legs), motelness persists in the sign. The visitors arrive, brake lights flashing, right at the door of their motel room.

If the giant road sign is the first intimation of the Magnolia Motel, repetition occurs in the wiry aerial that is the centre of the drawing, positioned between the sign and the moon, and attached to the motel building. The aerial alludes to the dispersed space of the motel - its repetitions (always the same and yet endlessly shifting) and its occupation of the electrical grid. The insubstantiality of the motel, its rapid disappearance towards the horizon line, is matched by its expression as receiver and transmitter of desires and needs. Steinberg's depiction anticipates current coded, formulaic conditions of architectural drawing.

Elevated above the motel office (distinguished from other units only by an arrow) the aerial seems like an esoteric code as it marks space through manipulations of lines and crossings. Like an architectural drawing the aerial is formed of instructional marks: two parallel lines indicate the thickness of matter and two arrow-heads mark a significant gap. The motel consisting only of division is crowned with a sign that articulates openness: a spangling vertical protuberance able to receive signals that fill the emptiness of space between the moon and the open road.

\section{The Motel plan}

The car park of the Magnolia Motel is elaborated in Steinberg's plan drawing in The Labyrinth. The drawing has a ground line that is the road from which the trajectories of the sign lead visitors into the car park around which are ranged motel units on three sides. The interior of the room is the closure of the road; only the parking lot mediates between the room and the openness for which it longs. And the road is the constant horizontal foundation of the motel, framing the mythic legend of motels in endlessly-remade road movies.

Steinberg's plan of the Magnolia Motel is diagram, notation and, as Frascari writes in an article about architectural plans, a "passe-partout" - a key that secures entrance everywhere, a pass key that makes the invisible visible (Frascari 1988: 97). The plan of the motel establishes the sign as a "key" in a field of data consisting of arrows, words, codes and trajectories. The key points into and out of the motel, highlighting a strange wilderness that exists beyond the motel units. Plans establish the limits of architecture constructing the landscape, the suburb and the world beyond as diminishing ripples of plan effects. In the 1960s and '70s the architectural plan was seen to be primarily utilitarian, attracting relatively little in the way of critical discussion. Marco Frascari's two articles on the architectural plans, Plans (1) and Plans (3), written in the late 1980s, were exceptions. Between the two articles is a gap, an absent volume, Plans (2), never published. 
Saul Steinberg Magnolia Motel Site Plan from Saul Steinberg Illuminations (C) Saul Steinberg, 1960/ARS.Licensed by VISCOPY 2010

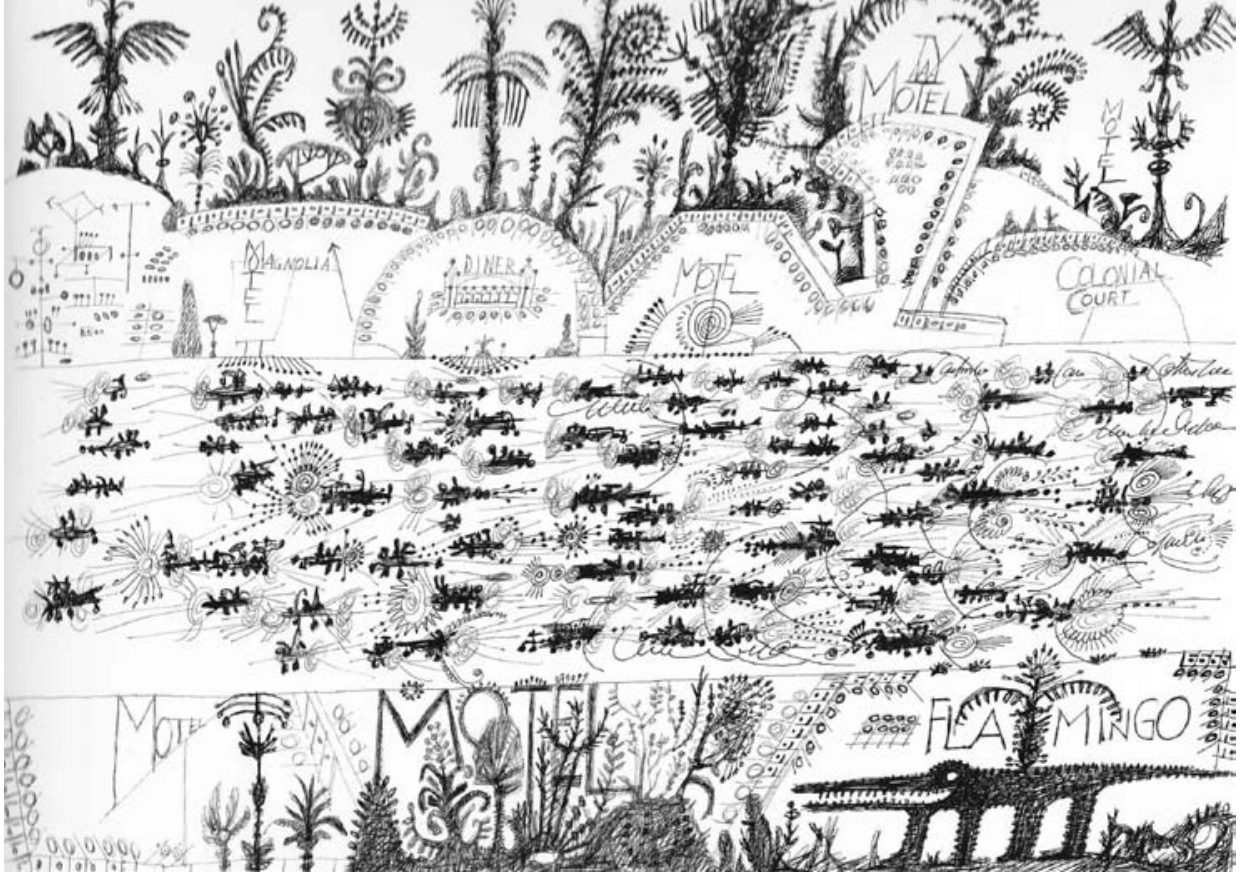

Plans (1) does not follow the usual pattern in which drawings operate as illustrative handmaiden to text. There is, instead, one page of writing followed by 34 continuous pages of drawn plans. The plans are rendered as distinct figure ground relationships, patterned marks, retrieved and separated from history. Frascari wrote that,

The best part begins when the plan is torn to pieces by history, defeated by events, chewed by time; when it reaches us as an incomprehensible collage of forgotten memories, as an unexpected and enigmatic structure, as existential lust, as pure decoration. (Frascari 1988: 97)

The sequence of plans presents exclusions, containments, black and white flickerings that accumulate. A series of possibilities - patterns of living and dying; tried, failed re-imagined. The sequence of 34 plans is long, wonderfully extended, exceeding expectations of text/image relationship. The plan asserted as figural, ornamental and scalar reactivates the operations of Steinberg's motel plan drawing.

Frascari wrote in the later article, Plans (3), that a

building is represented in plan in its entirety but there is no likeness between a plan representation and the original. The plan is neither a facsimile nor a symbol. It is not a model, but it represents a building through modeling, so that instead of reproducing the building the plan produces it poetically. (Frascari 1989: 126)

The plan does not exist as a model of the building-to-be but, instead, it engages in a prescient anticipation of building through the work of modeling - an active demonstration of the architecture. It is in the movement between the plans, the flicking of pages, in Plans (1) that the work of planning is revealed to be a geometrical marshalling of alterations, elaborations and eliminations: an assemblage of matter and space shaped formally and emotionally.

Steinberg's ink drawing of the Magnolia Motel plan questions the confines of the plan as drawing type and, like Frascari's text, it suggest that the limits of building and drawing are not the same. The Magnolia Motel is drawn past that which would aspire to be a built edge; the plan inscribes the forecourt with a tipped over sign promising cool air, and a road network that directs visitors into the motel. In the Magnolia Motel the units are drawn in code with a repeating horizontal dash/vertical dash, wall/body, arrayed in a long box. And as the units tilt into elevation they are drawn as containers with repeating door/window, 
door/window. The code signals both the separation of the units (the difficulty of acknowledging other occupants) and the collective dreams of the lonely and isolated. Twisting space from vertical to horizontal and back again, in a rhythm of illicit coitus, Steinberg creates a hybrid drawing that heightens and amplifies conditions of the plan.

Frascari begins Plans (1) by pointing out that "The drawing of a plan can be read as the abstraction of an idea; it can represent a sociological programme; it can be structured as a technological metaphor; it can - eventually - turn into an erotic image or be translated into a surreal apparition" (Frascari 1988: 97). He indicates the abstract qualities of the plan, its potential use value in terms of ideas, sociology or technology when the plan is deployed with the concerns of other disciplines in mind. He concurs with Le Corbusier's call for the plan as abstraction without austerity. Where Le Corbusier wrote that a "plan is not a pretty thing to be drawn like a Madonna's face" (Le Corbusier 1946: 46), Frascari will allow much more. In the repetitious beat of the black and white pattern of the 34 plans, page after page, a quickening of pulse is generated, a recognition of the bodily action of book, plan and architecture.

The plan of the Magnolia Motel refers to a logic of occupancy that drives calculations of loss and gain but it is seen to produce excess; it cannot be contained by the reason that might operate its construction. Outside the units, out the back in the land beyond the civilizing road, in the wilderness, the dreams and nightmares bred in the motel spawn and proliferate. Recumbent bodies lie in the motel units, registered in code - a dash - eyes shut tight in a horizontal line, dreaming of body parts and vegetative forms. Extending from the sleeping unit are clouds of bulgy excess in shapes of grasping fingers, genitalia and teeth. Steinberg records the fantasies, erotic, natural and threatening, generated by and exceeding the time of the motel. In stories of pleasure, illicit relationships and escape, monsters swell on the margins of the motel.

Frascari has written about the role of monsters in architecture: monsters that place "events within our vision that are capable of putting our thought out of place, of determining a buried but real possibility of meaning" (Frascari 1991: 32). In Steinberg's plan grotesque figures emanate from the motel and with their anatomical references they jolt expectations of the plan as a provider of measurable discrete information, signaling instead that which is known but repressed. The plan is coded with longing, with desire both cerebral and physical. The bulging, shape-shifting figures that churn out of the unit code undermine the completion and understanding of motel as type. Frascari noted that "The grotesque body is a body in the act of becoming. It is never finished, never completed; it is continually built, continually created; and it is the principle of the others' bodies" (Frascari 1991: 32).

If the Magnolia Motel is all sign, the site plan of the motel by Steinberg locates it within a field of signs, in an array of black savage spikiness. In the site plan the Magnolia Motel is situated with other motels on the banks of a wide and dangerous river/highway filled with ferocious black scribbles/cars/insects. Between the car park and a forest of wild, hybrid growth (variously vegetative, animal and architectural) the motels become a thickened boundary constructing the edge of an open and dangerous space as a fringe condition. Horizontally arranged along 
the river/road the Magnolia Motel is between a hybrid aerial/motel plan and a diner. Four unnamed motels are depicted along with the Flamingo and the Colonial Court that draw on an exoticizing or nostalgic distance for their names.

Site plans might generally be seen as conservative, as a commitment to a shared world, addressing context, situating architecture legally and in terms of the already existing. Steinberg, in contrast, depicts the site of the motel as hybrid, transformational and dangerous in a world that is exuberant, graphic and vigorous. Away from the architecture of the metropolis, situated in left-over space, constructing the margins and the marginal, the motels in the site plan become refuges - sheltering respite from the horrors of the highway and the looming nightmare zone beyond. Marked by imminent collisions, assumed loud noises and angry encounters, the road is shaped by an overall miasma of scratchy, ornamental atmosphere; the Flamingo motel is guarded by a large, smiling toothy crocodile. For Steinberg the crocodile is a symbol for dragons: "power at once evil and invincible, setting the terms for a world it aims only to devour" (Smith 2005: 164).

Steinberg's free drawings reveal parts of motel architecture that conventional drawing will not notice, even as he employs disciplinary language to locate the motel within architecture. His hybrid drawings, combinations of plans and elevations, plans and perspectives, expose movement as a structural, necessary condition of the architecture; the motel is never permanent and always experienced as transitory. The Steinberg motel participates in the road trip as an entanglement of linear forms of travel that repeat and return. Movement is caught in the momentary stillness of the motel room, framed by the speed of the open road, and is delineated in the repetitious code of closure and occupation. Rhythmical movement, the repetitive oscillation of bodies and rooms, repeated patterns of engagement, shape the flow of the drawings.

Repetitive movement causes the figure/ground of the architectural plans to shimmer in Frascari's articles on the plan, dissolving historic location and time in a blur. Even as the sharply wayward linearity of Steinberg's drawings mirrors the sudden flare of excess associated with the social programmes of the motel, so too the excessive repetition of the Frascari's plans induces a bodily response in the heartbeat rhythm of turning pages. Both Steinberg and Frascari trace and reveal architecture through a paring back and also an intensification, offering a sort of productive violence to the familiar orders and codes of architectural drawing. Steinberg's Magnolia Motel, gathered out of his collections, operates between cartoon, architectural drawing and building, inducing a slight destabilisation in each system or code; the Magnolia Motel as a fiction reveals the presence within the systems of representation of that which cannot be contained.

\section{References}

Benjamin, W. (1999). The Arcades Project. R. Tiedemann (Ed.) (H. Eiland and K. McLaughlin Trans.). Cambridge, Mass.: Belknap Press.

Bloomer, J. (1998). Pale Houses, Silenced Shadows. Assemblage 37, 46-67.

Foucault, M. (1967). Of Other Spaces. Retrieved 11 January 2010 from http://foucault.info/ documents/heteroTopia/foucault.heteroTopia.en.html

Frascari, M. (1988). Plans (1). Terrazzo, no. 1, 97. 
Frascari, M. (1989). Plans (3) Ichnography: The topical enigma of the architectural plan. Terrazzo, no. 3, 125-144.

Frascari, M. (c1991). Monsters of Architecture: Anthropomorphism in Architectural Theory. Savage, Md.: Rowman \& Littlefield.

Frascari, M. (2007a). Horizons at the Drafting Table: Filarete and Steinberg, Chora 5, 179-200.

Frascari, M. Architectural Synaesthesia: a hypothesis on the makeup of Scarpa's modernist architectural drawings. Retrieved 2 January 2010 from http://art3idea.psu.edu/synesthesia/documents/synesthesia_frascari.html

Frascari, M. (2007b). Introduction, From Models to Drawings, M. Frascari, J. Hale and B. Starkey (Eds.). New York: Routledge.

Le Corbusier (1946). Towards a New Architecture. London: The Architectural Press.

Lyotard, J. F. (c2006). Discourse, Figure. The Lyotard Reader and Guide. K. Chrome and J. Williams (Eds.). Edinburgh: Edinburgh University Press.

Meredith, M. (2002). John Hejduk - Reviews: New York, Artforum, http://findarticles. com/p/articles/mi_m0268/is_4_41/ai_95676031/

Morris, M. (1993). At Henry Parkes Motel. In John Frow and Meaghan Morris (Eds), Australian Cultural Studies: A Reader. (241-275) Leonards: Allen \& Unwin.

Nabokov, V. (2000). The Annotated Lolita, A. Appel (Ed.). London: Penguin edition.

Rehe, R. F. (2006). Legibility. In Graphic Design and Reading: Explorations of an Uneasy Relationship. G. Swanson (Ed.). New York: Allworth Press.

Rosenberg, H. (1978). Saul Steinberg. New York: Alfred A. Knopf in association with The Whitney Museum of American Art.

Smith, J. (2005). Steinberg at the New Yorker. New York: Harry N. Abrams Inc.

Steinberg, S. (1960). The Labyrinth. New York: Harpers \& Brothers Publishers.

Steinberg, S. with Buzzi, A. (2002). Reflections and Shadows. (John Shepley, Trans.). New York: Random House.

Treadwell, S. (2005). The Motel: An Image of Elsewhere, Space and Culture, May vol. 8, no. 2, 214-224.

Willer, T. (Curator) (2009). Saul Steinberg: Visual Writing, Catalogue: Tomi Ungerer Museum International Center Of Illustration, November 27th 2009 - February 28th 2010.

Vanishing America: Knoxville, Tennesse - Then and Now. Retrieved 30 December 2009 from http://www.swankpad.org/places/knoxvilletan/magnolia/magnolia.htm. 